\title{
Glucose intolerance and impairment of insulin secretion in relation to vitamin D deficiency in East London Asians
}

\author{
B.J.Boucher ${ }^{1}$, N.Mannan ${ }^{1}$, K. Noonan ${ }^{2}$, C.N. Hales ${ }^{3}$, S. J.W. Evans ${ }^{4}$ \\ ${ }^{1}$ Academic Medical Unit and Cellular Mechanisms Research Group, London Hospital Medical College, London, UK \\ ${ }^{2}$ Department of Clinical Chemistry, Royal London Hospital, London, UK \\ ${ }^{3}$ Department of Clinical Biochemistry, University of Cambridge, Addenbrookes Hospital, Cambridge, UK \\ ${ }^{4}$ Department of Epidemiology and Medical Statistics, The London Hospital Medical College, London, UK
}

Summary Vitamin D deficiency reduces insulin secretion and still occurs in East London Asians in whom the prevalence of diabetes mellitus is at least four times that of Caucasians. Vitamin D status was assessed in 44 of 65 non-diabetic subjects 'at risk' of diabetes (spot blood glucose level $>6.0 \mathrm{mmol} / 1<2 \mathrm{~h}$ post cibum, or $>4.6 \mathrm{mmol} / \mathrm{l}>2 \mathrm{~h}$ post cibum on two separate occasions) and in 15 of 60 age and sexmatched 'low-risk' control subjects who attended for oral glucose tolerance test (OGTT) after screening of 877 omnivorous subjects not known to have diabetes. It was found that $95 \%$ of at-risk and $80 \%$ of lowrisk subjects were vitamin $\mathrm{D}$ deficient (serum 25-hydroxy-vitamin $\mathrm{D}<11 \mathrm{ng} / \mathrm{ml}$ ). Diabetes was present in 16, impaired glucose tolerance in 12 and normoglycaemia in 19 at-risk subjects, impaired glucose tolerance in 2, and normoglycaemia in 13 low-risk subjects. Correlations of 30-min OGTT blood glucose, specific insulin and C-peptide levels with 25-hydroxy-vitamin $\mathrm{D}$ concentrations in 44 at-risk subjects were $-0.31 \quad(p=0.04), 0.59(p=0.0001)$ and 0.44 $(p=0.006)$. In 15 'not-at-risk' subjects 30-min OGTT specific insulin and C-peptide levels correlated with 25-hydroxy-vitamin $\mathrm{D}, r=0.39(p=0.04)$ and 0.16 $(p=0.43)$, respectively. Serum alkaline phosphatase concentration was higher in at-risk than not-at-risk subjects (59.6 vs $46.5 \mathrm{IU} / \mathrm{l}, p=0.012$ ); corrected calcium concentrations were comparable (2.38 vs $2.39 \mathrm{mmol} / \mathrm{l}, \quad p=0.7)$. Following treatment with 100,000 IU vitamin D by i.m. injection, specific insulin, C-peptide [30 min on OGTT] and 25-hydroxyvitamin D concentrations had risen 8-12 weeks later [means $\pm \mathrm{SD}]$ from $57 \pm 62$ to $96.2 \pm 82.4 \mathrm{mU} / 1[p=$ $0.0017], 1.0 \pm 0.4$ to $1.7 \pm 0.8 \mathrm{pmol} / \mathrm{ml}[p=0.0001]$ and $3.6 \pm 1.8$ to $13.5 \pm 7.4 \mathrm{ng} / \mathrm{ml}[p=0.0001]$, (but not to low-risk group values of $179 \pm 89 \mathrm{mU} / 1$, $2.7 \pm 1.14 \mathrm{pmol} / \mathrm{ml}$ and $8.16 \pm 6.4 \mathrm{ng} / \mathrm{ml}$ ), respectively. Both total serum alkaline phosphatase and corrected calcium concentrations rose following vitamin $\mathrm{D}$ treatment in the at-risk subjects by $11.1 \pm 8.22$ (from 44 to $55 \mathrm{IU} / 1$ ) and $0.15 \pm 0.18,(2.43$ to $2.57 \mathrm{mmol} / \mathrm{l})$, respectively $(p=0.004)$. Abnormal glucose tolerance was unchanged by vitamin $D$ treatment. The value of early and sustained repletion with vitamin $\mathrm{D}$ in diabetes prophylaxis should be examined in communities where vitamin $\mathrm{D}$ depletion is common. [Diabetologia (1995) 38: 1239-1245]

Key words Non-insulin-dependent diabetes mellitus, vitamin $\mathrm{D}$, vitamin $\mathrm{D}$ deficiency, total insulin, specific insulin, proinsulin, 32,33 split proinsulin, C-peptide, glucose intolerance.
Received: 5 July 1994 and in final revised form: 19 April 1995

Corresponding author: Dr. B.J. Boucher, Royal London Hospital, London E11BB, UK

Abbreviations: OGTT, Oral glucose tolerance test; IGT, impaired glucose tolerance; p.c., post cibum; CV, coefficient of variation; NEFA, non-esterified fatty acids.
The prevalence of non-insulin-dependent diabetes mellitus (NIDDM) is greater in Asian immigrants to the United Kingdom than in the Caucasian population; furthermore, Asians develop NIDDM earlier in life than their Caucasian contemporaries $[1,2]$. Vitamin D depletion still presents as rickets and osteomalacia in Asians in the UK [3]. In experimental animals vitamin $\mathrm{D}$ is necessary for normal release of insulin and for the maintenance of normal glucose toler- 
ance. Following prolonged deficiency, impairment of insulin secretion develops and diabetes becomes irreversible $[4,5]$. Administration of 1,25 calcitriol improves insulin secretion and corrects early glucose intolerance in patients with renal failure [6]. Calcium appears to be necessary for normal insulin secretion $[7,8]$ and correction of hypocalcaemia in nutritional rickets and hypoparathyroidism has been shown to correct both insulin secretion and impaired glucose tolerance in a group of eight patients [9]. We therefore examined the vitamin $\mathrm{D}$ status by oral glucose tolerance test (OGTT) of subjects screened as "atrisk" of diabetes, during a study of dietary factors in diabetes aetiology in East London Asians. Once vita$\min \mathrm{D}$ deficiency was found to be common in those screened as at-risk of diabetes we proceeded to examine glucose tolerance, secretion of insulin and of proinsulin-like molecules (as well as fasting serum calcium, parathormone and alkaline phosphatase concentrations) in relation to vitamin D status.

\section{Subjects and methods}

One thousand British Asians of Bangladeshi origin living in the London Borough of Tower Hamlets were contacted at the surgeries of their general practitioners as consecutive "well" attenders, or through practice records. The study was approved by the district ethics committee. After giving informed consent volunteers answered a dietary questionnaire and provided a personal history of diabetes. Spot blood glucose level was measured on a finger-prick sample using BM 1-44 stix (Boehringer Mannheim Ltd UK, Lewes, Sussex, UK) with a reflolux meter by a single observer (N.M.). The results were validated using a glucose oxidase specific micro-technique (Beckman Instruments, Palo Alto, Calif., USA), with a coefficient of variation for glucose levels below $25 \mathrm{mmol} / 1$ of less than $3 \%$. Only subjects "at-risk" of diabetes and their "notat-risk" control subjects are considered further in this report. Sixty-five subjects not previously known to have diabetes, all of whom were meat and fish eaters, but with spot blood glucose levels greater than $6.0 \mathrm{mmol} / \mathrm{l}$ less than $2 \mathrm{~h}$ post cibum (p.c.), or greater than $4.6 \mathrm{mmol} / 1$ at times greater than 2 h p.c. on two separate occasions, were regarded as at-risk of diabetes [10] and were invited for a standard 75-g OGTT [11]; 57 attended. In 44 of these subjects $0-, 30$ - and 120-min venous sampling was achieved. Multiple venous sampling being unacceptable to many subjects from the ethnic group under study, finger-prick sampling was used for one or more sampling times in the remaining 13 subjects. Plasma glucose concentrations were measured by standard hexokinase methodology using a Discrete Analyser (Du Pont Dimension SIMS Clinical Chemistry System; Wilmington, Del., USA). Aliquots of serum separated within 2 h of sampling were stored at $-20^{\circ} \mathrm{C}$ before assay. Serum total insulin was measured by an in-house radioimmunoassay using Guildhay antibody and National Institute of Biological Standards (UK) human insulin standard 66/304, (CV between or within assay $<7.5 \%$; cross-reaction with pro-insulin $100 \%$ ). Specific human insulin was measured by enzyme immunoassay (Medgenix, Florius, Belgium) (CV<10\%, cross-reaction with pro- and 32,33 split proinsulin, $0 \%$ ). Cpeptide concentrations were measured by radioimmunoassay (Medgenix) $(\mathrm{CV}<7.2 \%)$. Proinsulin and 32,33 split proinsulin concentrations were assayed by immunoradiometric assay $(\mathrm{CV}<7.5 \%)$ and serum 25-hydroxy-vitamin D concentrations, reflecting vitamin $D$ status [12], by radioimmunoassay (Incstar, Minn., USA; lower limit of detection $2.1 \mathrm{ng} / \mathrm{l}$, within and between assay $\mathrm{CV}<6.6 \%$ ). Total fasting serum calcium, alkaline phosphatase and albumin concentrations were measured with the Bayer DAX 48 Analyser (Basingstoke, UK). Calcium concentrations were corrected to a serum albumin level of $46 \mathrm{~g} / \mathrm{l}$. Serum intact parathormone was measured by immunoradiometric assay in at-risk subjects (Nichols Institute Diagnostics Ltd, Saffron Walden, Essex, UK; within and between assay $\mathrm{CV}<5 \%$ ).

Of the 42 at-risk subjects identified as vitamin D-deficient (serum 25 hydroxy vitamin $\mathrm{D}<11.0 \mathrm{ng} / \mathrm{ml}$ [12]) at initial OGTT, 22 accepted the offer of treatment from their general practitioner with a single bolus injection of $100,000 \mathrm{IC}$ of vitamin D and returned for repeat OGTT 8-12 weeks later, with finger-prick sampling at 0 and 120 min for blood glucose estimation, and limited venous sampling at $30 \mathrm{~min}$. The first OGTTs were carried out between December 1991 and May 1992. Sixty-five subjects matched for age and sex to those of the at-risk group but with spot blood glucose levels below the at-risk values given above were invited for OGTT, and 15 attended, all of whom were meat and fish eaters. These subjects acted as not-at-risk control subjects for assessment of glycaemic and vitamin D status. Post-repletion OGTTs following vitamin D treatment of the at-risk group of OGTTs in the lowrisk group were carried out concurrently between January and March 1993.

\section{Statistical analysis}

Statistical analyses used paired and independent sample $t$-tests and non-parametric equivalents and multiple regression with the computer program STATA (Stata Corp, College Station, Texas, USA), version 3.1 , on an IBM PC compatible computer. Parametric tests including correlation used log transformed data where they were positively skewed; Spearman rank correlation was also used. The significant correlations given were each confirmed to remain significant when recalculated after exclusion of any outliers. Correlations of differences between post- and pre-treatment results were made with the mean of the pre- and post-treatment findings, to minimize the effect of regression towards the mean [13]. Data are given as mean $\pm \mathrm{SD}$.

\section{Results}

Of the 993 subjects who completed the questionnaire and were screened, 116 were found to have known diabetes $(12 \%)$ ). Spot blood glucose tests identified 65 subjects as at-risk for diabetes as defined above. Forty-seven of these subjects completed OGTTs with venous sampling for glucose at 0,30 and $120 \mathrm{~min}$ and of these 19 were normal, 12 showed impaired glucose tolerance (IGT) and 16 had diabetes as defined by World Health Organization criteria [11]. The prevalence of diabetes in the group as a whole, NIDDM in all cases, was therefore at least $14 \%$. There were 22 women and 22 men in the at-risk and 10 women and 5 men in the not-at-risk group in whom 25-hydroxyvitamin $\mathrm{D}$ was measured (chi-squared $=0.09$ for the 


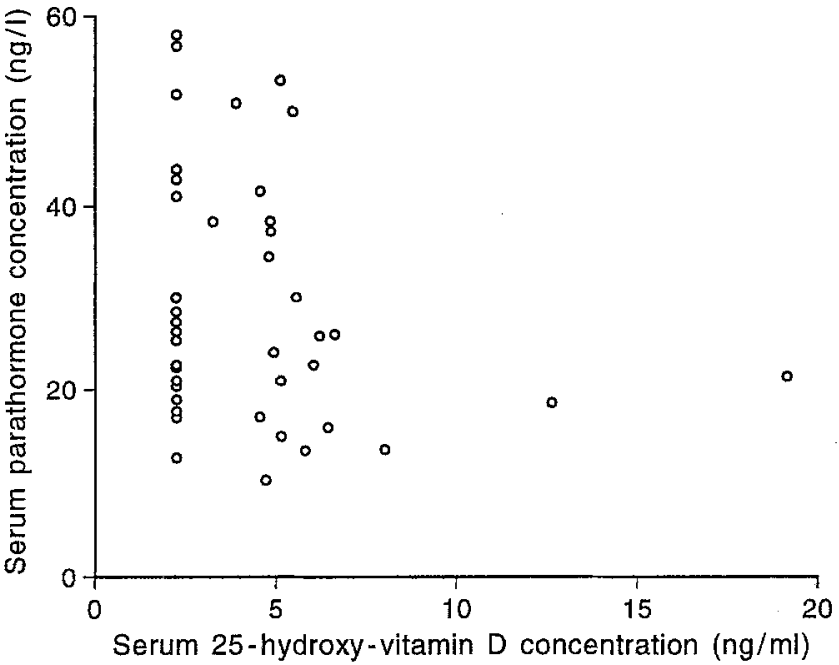

Fig. 1. Serum parathormone and 25-hydroxy-vitamin D concentrations in 44 Asian subjects, not known to have diabetes, at-risk of diabetes on screening blood glucose test (spot values $>6.0 \mathrm{mmol} / 1$ less than $2 \mathrm{~h}$ p.c. or $>4.6 \mathrm{mmol} / 1$ more than $2 \mathrm{~h}$ p.c. on two occasions)

difference in sex ratio $(p=0.77))$. The mean ages of subjects in these groups were $42,48,48$, and 55 years, respectively and the mean \pm SD ages of at-risk compared to not-at-risk subjects were $44.9 \pm 13.0$ and $49.9 \pm 8.7$ respectively $(p=0.17)$. There were no differences between body mass index (BMI) in the atrisk group as a whole at $25.9 \pm 3.95 \mathrm{~kg} / \mathrm{m}^{2}$ [or in the subgroup treated with vitamin $D$, at $26.2 \pm 4.5 \mathrm{~kg} / \mathrm{m}^{2}$ $(p=0.46)]$ and the BMI of the not-at-risk group at $25.2 \pm 5.2 \mathrm{~kg} / \mathrm{m}^{2}(p=0.55)$. Of the 44 at-risk subjects providing adequate serum sampling for immunoassays at OGTT, 42 were vitamin D-depleted (serum25 -hydroxy-vitamin D levels $<11 \mathrm{ng} / \mathrm{ml}$ ). Vitamin D concentrations were $5.2 \pm 4.6,3.7 \pm 1.4$, and $3.2 \pm$ $1.5 \mathrm{ng} / \mathrm{ml}$ in those who had normal, IGT, or diabetic results, respectively on OGTT, and significantly higher at $8.16 \pm 6.4 \mathrm{ng} / \mathrm{ml}$ in the not-at-risk control than in the at-risk subjects, $p=0.01$. The 25-hydroxy-vitamin $D$ was not affected by sex, or related to age or to BMI in any group of subjects. Mean serum parathormone concentration in the at-risk group was $31.0 \pm 3.0$, (range 18.3-39.3) as compared to $23.8 \pm 2.4 \mathrm{ng} / \mathrm{l}$, (range 19.6-28.0) in 21 healthy Caucasians of comparable age examined at the same time of year (and assayed together with the at-risk samples, $p=0.0001$ [14]). There was a negative, though not striking, correlation of parathormone with serum-25hydroxy-vitamin D in the 33 subjects in the at-risk group in whom adequacy of venous sampling allowed fasting parathormone to be measured, $r=-$ $0.27, p=0.09$ (Fig. 1). Specific serum insulin concentrations at $30 \mathrm{~min}$ on OGTT were lower in the 44 atrisk subjects compared to those of the 15 not-at-risk subjects, $37 \pm 26$ vs $178 \pm 89 \mathrm{mU} / \mathrm{l}(p=0.0001$, MannWhitney test) as were C-peptide concentrations at $30 \mathrm{~min} ; 1.1 \pm 0.45 \mathrm{pmol} / \mathrm{ml}$ in the at-risk group vs $2.7 \pm 1.1 \mathrm{pmol} / \mathrm{ml}$ in the not-at-risk subjects ( $p=0.001$, Mann-Whitney test) (Table 1$)$. There was no relationship of 30-min OGTT specific insulin concentration with age or with BMI, and no difference in the findings by sex. During OGTT 30-min plasma glucose concentrations were negatively related to vitamin D status in the at-risk group as well as in the combined at-risk and not-at-risk subjects $(r=-0.31$ and -0.32 , respectively, $p=0.04$ ), as were $2-h$ values in the at-risk group $(r=-0.31, p=0.04)$. Both total and specific human insulin and C-peptide concentrations at $30 \mathrm{~min}$ on OGTT in the untreated at-risk group were correlated positively with serum-25-hydroxy-vitamin D concentration $(r=0.73, p=0.0001$; $r=0.59, p=0.002$ and $r=0.44, p=0.006$, respectively [Spearman ranking]) (Fig. 2). Multiple regression analysis confirmed that total and specific insulin

Table 1. OGTT data in 44 at-risk, 15 not-at-risk subjects, and in 22 of the 44 at-risk subjects treated with vitamin D

\begin{tabular}{|c|c|c|c|c|}
\hline \multirow[t]{3}{*}{ Variable } & \multirow[b]{3}{*}{$(n=44)$} & \multicolumn{3}{|l|}{ Group } \\
\hline & & \multicolumn{2}{|l|}{ At risk } & \multirow{2}{*}{$\begin{array}{l}\text { Not-at-risk } \\
(n=15)\end{array}$} \\
\hline & & $\begin{array}{l}\text { Pre-vitamin D } \\
(n=22)^{\mathrm{g}}\end{array}$ & Post-vitamin D & \\
\hline \multicolumn{5}{|l|}{$30 \mathrm{~min}$} \\
\hline Plasma glucose $(\mathrm{mmol} / \mathrm{l})$ & $10.8 \pm 3.6$ & $9.95 \pm 3.4$ & $11.75 \pm 4.5^{\mathrm{g}}$ & $9.5 \pm 1.8^{c}$ \\
\hline Specific insulin (mIU/1) & $36.9 \pm 26.1$ & $36.8 \pm 24.4$ & $96.2 \pm 82.4^{\mathrm{a}}$ & $178 \pm 88.5^{\mathrm{b}}$ \\
\hline C-peptide (pmol $/ \mathrm{ml})$ & $1.08 \pm 0.45$ & $0.76 \pm 0.62$ & $1.7 \pm 0.2^{\mathrm{a}}$ & $2.7 \pm 1.14^{c}$ \\
\hline Proinsulin (pmol/l) & $15.4 \pm 12.9$ & $15.33 \pm 11.9$ & $13.4 \pm 9.9^{\mathrm{e}}$ & $13.1 \pm 10.5^{\mathrm{f}}$ \\
\hline 32,33 Proinsulin (pmol/1) & $40 \pm 30.2$ & $41.8 \pm 30.2$ & $37.8 \pm 27.6^{\mathrm{d}}$ & $48.13 \pm 35.2^{\mathrm{g}}$ \\
\hline \multicolumn{5}{|l|}{$120 \mathrm{~min}$} \\
\hline Plasma glucose $(\mathrm{mmol} / \mathrm{l})$ & $11.04 \pm 5.36$ & $11.13 \pm 5.73$ & $12.5 \pm 6.6^{\mathrm{a}}$ & $7.2 \pm 1.57^{\mathrm{b}}$ \\
\hline
\end{tabular}

" $p<0.01$ for differences in means in 22 "at-risk" group; pre- vs post-vitamin D treatment;

b $p<0.01$ and ${ }^{c} p<0.0001$ for differences in means in 44 "at-risk" vs "low risk" control subjects;

${ }^{\mathrm{d}} p>0.5$ and ${ }^{\mathrm{e}} p>0.3<0.5$ for differences in means as for ${ }^{\mathrm{a}}$;

${ }^{\mathrm{f}} p>0.5$ and $^{\mathrm{g}} p>0.3<0.5$ as for $^{\mathrm{b}}$ and $^{\mathrm{c}}$

g See methods for details 


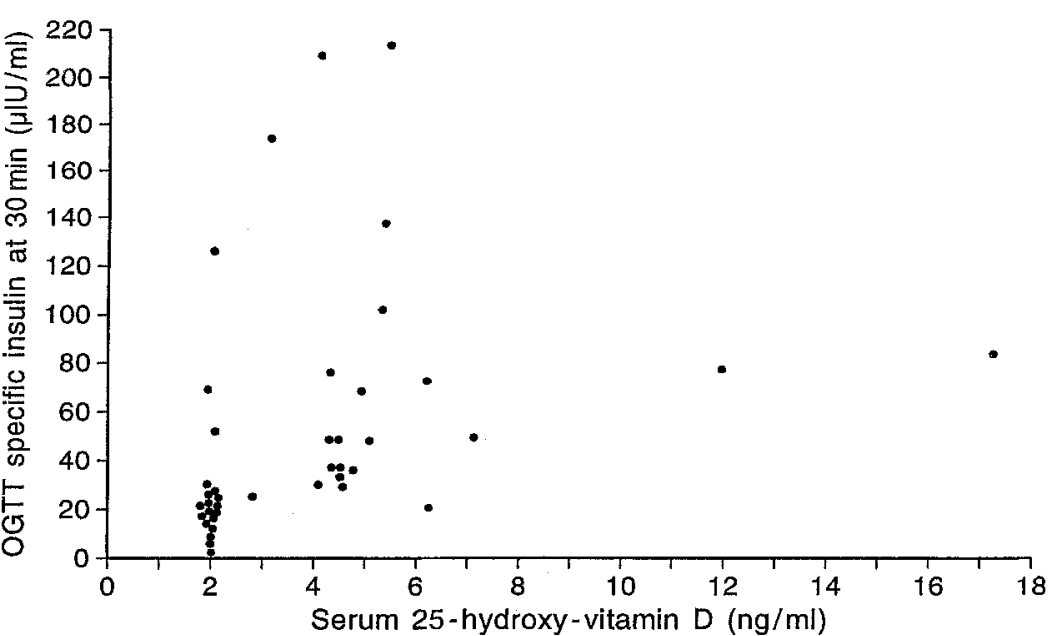

30-min-OGTT serum C-peptide
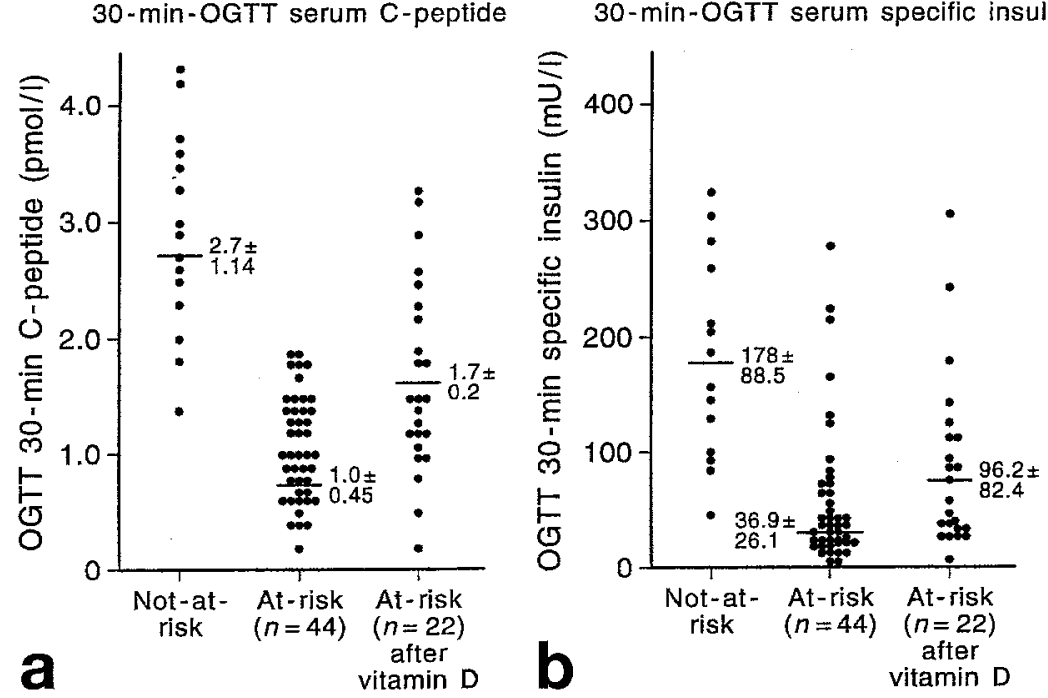

30-min-OGTT serum specific insulin
Fig. 2. Serum 30-min specific insulin with fasting 25-hydroxy-vitamin D concentrations in 44 subjects not known to have diabetes, and at-risk of diabetes on screening blood glucose (spot values $>6.0 \mathrm{mmol} / 1$ less than 2 h p.c. or $>4.6 \mathrm{mmol} / 1$ more than 2 h p.c. on two occasions). 25 -hydroxyvitamin D values of $2.1 \mathrm{ng} / \mathrm{l}$, the lower limit of detection of the assay, are shown spread out over $1.5-2.1 \mathrm{ng} / \mathrm{l}$ for clarity
Fig.3. (a) Serum C-peptide and (b), specific insulin concentrations at $30 \mathrm{~min}$ on OGTT in 44 subjects not known to have diabetes and not-atrisk or at-risk of diabetes on screening, (where atrisk is defined by spot blood glucose values $>6.0 \mathrm{mmol} / 1$ less than $2 \mathrm{~h} \mathrm{p.c.} \mathrm{or}>4.6 \mathrm{mmol} / \mathrm{l}$ more than $2 \mathrm{~h}$ p.c. on two occasions), and in the subgroup of 22 of the 44 at-risk subjects who had been treated with 100,000 IU of vitamin D by injection 8-12 weeks before repeat OGTT. Mean \pm SD and C-peptide concentrations were each correlated with 25-hydroxy-vitamin D concentrations independently of age, sex or BMI. Corrected serum calcium concentrations were comparable in at-risk and notat-risk subjects, mean 2.37 compared to $2.39 \mathrm{mmol} / \mathrm{l}$ ( $p=0.69$ ), whilst serum alkaline phosphatase concentrations were higher in the at-risk subjects, mean $59.6 \mathrm{U} / 1$, compared to $46.5 \mathrm{U} / \mathrm{l}$ in not-at-risk subjects $(p=0.012)$.

Measured 8-12 weeks after vitamin D injection, serum alkaline phosphatase had risen from 44 to $55 \mathrm{U} / 1$, a rise of $11.1 \pm 8.22 \mathrm{U} / 1, p=0.00005$, and corrected serum calcium from 2.43 to $2.57 \mathrm{mmol} / 1$, a rise of $0.15 \pm 0.18 \mathrm{mmol} / 1, p=0.004$, no value rising above the normal range. Specific insulin concentration at $30 \mathrm{~min}$ on OGTT had risen in the 22 treated subjects by $43.0 \pm 65 \mathrm{mU} / 1,(p=0.0001))$ and C-peptide concentration had risen by $0.74 \pm 0.61 \mathrm{pmol} / 1$, ( $p=0.0001$ ), (Table 1, Figs. 3, 4, 5 for changes in individuals). Serum 25-hydroxy-vitamin D concentrations were $13.5 \pm 7.4 \mathrm{ng} / \mathrm{ml}$ in the 22 treated subjects compared to their pre-treatment values of $3.6 \pm$
$1.8 \mathrm{ng} / \mathrm{ml}, p=0.0001$. The correlations of $30-\mathrm{min}$ OGTT specific insulin and C-peptide with 25-hydroxy-vitamin $\mathrm{D}$ concentration in the 22 at-risk subjects studied after vitamin $\mathrm{D}$ treatment were $r=0.47$ $(p=0.059)$ and $r=0.12(p=0.4)$. 30-min OGTT proinsulin concentration was somewhat higher in the atrisk group before $(15.33 \pm 11.95 \mathrm{pmol} / 1)$ than after treatment $(13.8 \pm 8.6 \mathrm{pmol} / \mathrm{l})$, or than in the not-atrisk group, $(13.1 \pm 10.5 \mathrm{pmol} / 1) .32,33$ split proinsulin concentration was similar in the at-risk ( $40 \pm$ $30.15 \mathrm{pmol} / \mathrm{l})$ and the not-at-risk $(48.13 \pm 35.2 \mathrm{pmol} /$ 1) groups. Following vitamin $D$ treatment 32,33 split proinsulin concentration fell marginally from $41.8 \pm 30.2$ to $37.8 \pm 27.6 \mathrm{pmol} / 1$ in contrast to the significant rise found in specific insulin concentration.

None of the 15 not-at-risk control attenders had diabetes, though two (12.5\%) had IGT; their 30-min OGTT true insulin and C-peptide concentrations were within the normal ranges at $178 \pm 88.53 \mathrm{mU} / \mathrm{l}$ and $2.7 \pm 1.14 \mathrm{pmol} / \mathrm{ml}$, respectively and 12 were vitamin D depleted. The 25-hydroxy-vitamin D concentration was significantly higher in these subjects at 


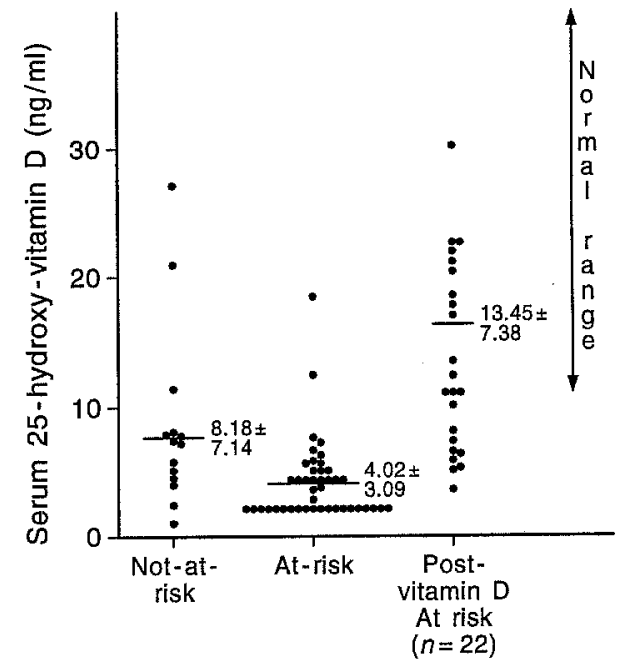

Fig. 4. Serum 25-hydroxy-vitamin D concentrations in 44 subjects not known to have diabetes, not-at-risk and at-risk of diabetes on blood glucose screening, (where at-risk is defined by spot glucose values of $>6.0 \mathrm{mmol} / 1$ less than $2 \mathrm{~h}$ or $>4.6 \mathrm{mmol} / \mathrm{l}$, more than $2 \mathrm{~h}$ p.c. upon two occasions) and in 22 of the at-risk subjects $8-12$ weeks after treatment with vita$\min \mathrm{D}, 100,000 \mathrm{IU}$ in oil, by intramuscular injection. Mean $\pm S D$
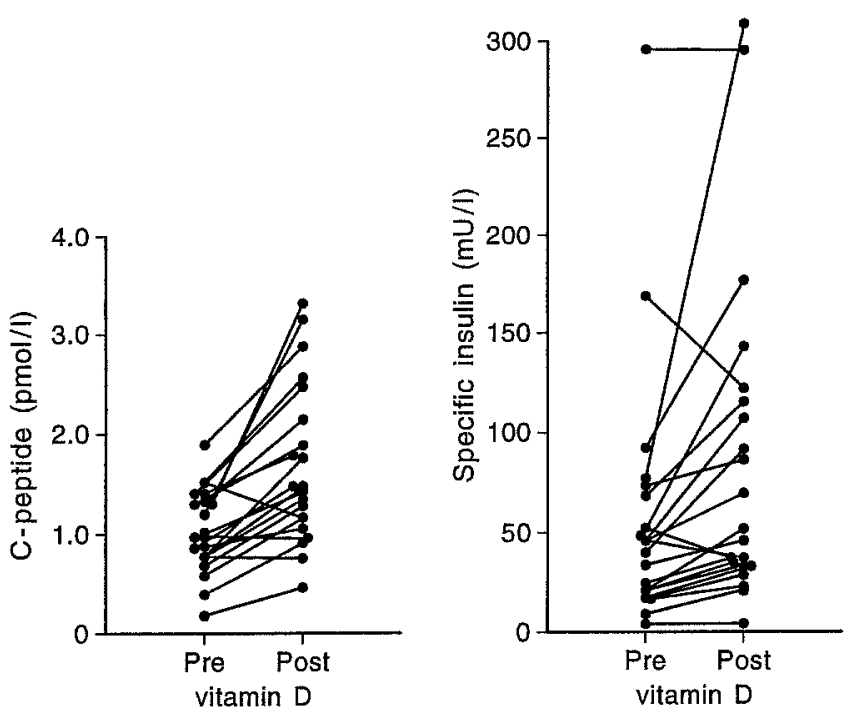

Fig. 5. Individual changes in C-peptide and specific insulin (30min OGTT concentrations) before and after treatment of 22 subjects not known to have diabetes and found to be at-risk of diabetes (where at-risk is defined by spot glucose values $>6.0 \mathrm{mmol} / 1$ less than $2 \mathrm{~h} \mathrm{p.c}$. or $>4.6 \mathrm{mmol} / \mathrm{l}$ more than $2 \mathrm{~h}$ p.c. on two occasions), with vitamin $D$

$8.18 \pm 7.14 \mathrm{ng} / \mathrm{ml}(p=0.001)$, than in the 22 at-risk subjects before vitamin $D$ treatment. OGTT (30min) specific insulin concentration in the not-at-risk control group, as in the at-risk group, correlated positively with 25 -hydroxy-vitamin $\mathrm{D}$ concentration $(r=0.389, p=0.05)$ but the correlation of C-peptide with vitamin $D$ status was not significant in this group $(r=0.16, p=0.12)$. No at-risk subject re-at- tending for OGTT after vitamin D treatment was on oral hypoglycaemic agents though dietary advice had been given to subjects initially found to have diabetes. Glucose tolerance at the second OGTT, approximately 1 year after the first attendance and at a comparable time of year, was unaltered in 15 subjects, worsened in six (normal to IGT in two, IGT to diabetes in four) and improved in two (IGT to normal). The changes in 30-min OGTT 32,33 split proinsulin concentrations were negatively correlated to the means of the concentrations of 25-hydroxy-vita$\min \mathrm{D}$, measured before and after treatment with vitamin $\mathrm{D}(r=-0.32, p=0.12, n=19$, three samples being inadequate for assay), but there was no relationship between changes in split proinsulin and vitamin D status. Neither pro- nor 32,33 split proinsulin concentrations at $30 \mathrm{~min}$ on OGTT related to vitamin D status in either the untreated at risk subjects $(r=0.12, p=0.45$ and $r=0.067, p=0.69$ respectively, $n=40$ ), or in the not-at-risk control subjects ( $r=$ $-0.20, p=0.48$ and $r=-0.06, p=0.84$, respectively $n=14$, one sample being inadequate for proinsulin assay).

\section{Discussion}

There is no single accepted method of screening for diabetes. The method chosen for the present survey has been used previously in screening British Asians for diabetes [10]. While not all the at-risk subjects identified in the present survey agreed to OGTT, and not all attenders for OGTT agreed to full venous sampling, a problem also found in communities in India [15], the numbers studied were sufficient to demonstrate a relationship between vitamin $D$ status and both insulin and C-peptide concentrations at $30 \mathrm{~min}$ on OGTT, reflecting secretion/release into the bloodstream, in subjects at-risk and not-at-risk of diabetes at screening. Vitamin D has been shown to be required for maintenance of normal glucose tolerance and insulin release in animals $[4,5]$, and is believed to act in the same way in man, possibly by ensuring the availability of free calcium ions $[9,16]$. Prolonged depletion leads to failure of insulin secretion which over time becomes irreversible [17]. While rickets and osteomalacia are still seen due to vitamin D depletion in our local Asian community [3], such problems are less common than was the case 10 or more years ago. The finding of inadequate vitamin $\mathrm{D}$ repletion, as evidenced by reduced serum 25 hydroxy-vitamin D concentrations, in 42 of 44 at-risk and 11 of 15 not-at-risk subjects was therefore unexpected. The reduction in absorption of vitamin $\mathrm{D}$ found with age [18] was unlikely to account for the reduction in concentrations of vitamin D in at-risk subjects since they were younger than the not-at-risk subjects. It was also unlikely that the increased risk 
of vitamin D depletion in female Asians [19] accounted for the greater depletion found in the at-risk group since the proportion of females to males was greater in the not-at-risk group $(2: 1)$, than in the atrisk group $(1: 1)$. True insulin secretion and abnormalities of insulin secretory profiles have not to our knowledge been examined previously in relation to vitamin $\mathrm{D}$ status in man, though proinsulin cleavage endopeptidases have been found to be calcium dependent [20], and increases in immunoassayable insulin during OGTT reported in patients with NIDDM given one-alpha-hydroxycalciferol for 3 weeks [21].

The reduction in parathormone concentration with increased vitamin D status seen in our subjects, and the rise in corrected serum calcium and in serum alkaline phosphatase following treatment with vitamin $D$ suggest that reduction in serum 25-hydroxy-vitamin $D$ concentration was associated with deficiency of vitamin $\mathrm{D}$. The finding of significant correlations for both 30-min OGTT C-peptide and specific insulin with vitamin $\mathrm{D}$ status in both the at-risk and not-atrisk groups suggests that vitamin $\mathrm{D}$ repletion may be of value for the maintenance of normal insulin secretion in man. 25-hydroxy-vitamin $D$ concentrations were not as high in the not-at-risk group of British Asians as is normal for British Caucasians at comparable times of year [22], though they were higher than in at-risk subjects. It is possible, therefore, that longterm vitamin $\mathrm{D}$ depletion could contribute to the increased prevalence of diabetes seen in Asians migrating to Northern Europe as compared to that of indigenous Caucasians. Early correction of vitamin D depletion has been shown to restore both insulin secretion and normoglycaemia in dialysis patients developing glucose intolerance with failing 1-hydroxylation of 25 -hydroxy-vitamin D $[6,23]$ and in earlier case reports of treatment of vitamin $\mathrm{D}$ deficiency in subjects with glucose intolerance [9]. As in previous reports of treatment with vitamin $D$ or its active di-hydroxy form in four vitamin D-depleted patients with established diabetes [17], and in 35 patients with NIDDM [24], we found no improvement in abnormal glucose tolerance in our 22 vitamin D-treated subjects despite improvement in insulin output. It is unlikely therefore that such therapy would be of value in established human diabetes. Furthermore, there has been no suggestion of increases in insulin secretion with vitamin D supplementation in replete adults [25]. It is unlikely that the increases in insulin secretion we describe following vitamin $\mathrm{D}$ treatment were related to dietary treatment of diabetes since the increases were largest in those who remained normoglycaemic. While the failure to correct diabetes in our study was disappointing, and specific insulin secretion was not fully restored despite improvement in insulin secretory profiles, the increases in serum 25 -hydroxy-vitamin $D$ that were achieved were modest and did not reach normal values. Maintenance of vitamin D reple- tion over time might prove more effective. The finding that insulin and C-peptide responsiveness after 1,25 $(\mathrm{OH}) \mathrm{D}$ treatment were negatively correlated with duration of diabetes is of interest in this context [25], as is the report of improved glycaemia in diabetic patients with osteomalacia after treatment with large doses $(42,000-85,000 \mathrm{IU})$ of vitamin D daily [26]. Diabetes in a male Dutch population group over 60 years old has been shown to be reduced in relation to increases in long-term fish consumption: though vitamin $\mathrm{D}$ intake was not discussed [27], the vitamin D-rich herring family was noted to contribute to fish intake. This finding strengthens the suggestion that maintenance of vitamin $\mathrm{D}$ repletion might contribute to the avoidance of diabetes, a hypothesis which we are about to test with a prospective double blind trial of treatment of vitamin $\mathrm{D}$ depletion.

The increased cardiovascular mortality suffered by British Asians, and its onset at an earlier age than in indigenous Caucasians, has been attributed to the increased prevalence of diabetes in this and in similar ethnic groups [28]. The 32,33 split-proinsulin concentrations have been shown to be increased in early glucose intolerance and to correlate with risk factors for cardiovascular disease [29], but it is not known whether correction of abnormal insulin secretory profiles might have wider implications. It has been suggested that disorders which increase in prevalence with increasing latitude, and present more commonly in winter, such as ischaemic heart disease, could prove to relate to vitamin D deficiency [30]. This suggestion is supported by the reductions in NEFA concentrations $[9,21]$ and in insulin resistance $[9]$ reported with correction of vitamin $\mathrm{D}$ depletion in man, to which secondary hyperparathyroidism has been suggested to contribute [31]. Examination of dietary information from the survey of which the present study is a part has shown initial serum 25-hydroxy-vitamin D concentrations in at-risk subjects at OGTT to be related to the consumption of fish; a relationship found in both at-risk and not-at-risk subjects $(p<0.04$ and $<0.02$, respectively) [14]. The vitamin D content of fish, especially oily fish, could therefore contribute to its known cardioprotective effects [32].

Acknowledgements. The authors are grateful to Dr. G. Dutt and Dr. V.Sarwar of The Florida Street Health Centre, London, and Dr. S. Ahmed and Dr. R. Rahman of The Hackney Road Practice, London, for permission to approach their patients, and to Dr. G. Dutt for invaluable advice on the design of the study. We thank the local people who assisted us with this research, Sister Ms M.Denoon and staff nurse Ms. L. Davies for carrying out OGTTs and Dr. G. John of Clinical Chemistry for assistance in establishing and validating the blood glucose techniques used for screening and OGTTs, Dr. T. A.B. Sanders for advice and facilities (to N.M.) for the measurement of circulating fish oils, to the Special Trustees of The Royal London Hospital for grant support (to B. J.B.) and also the Medical Research Council and the British Diabetic Association for grant support (to C.N.H.) for this work. 


\section{References}

1. Mather HM, Keen H (1985) The Southall Diabetes Survey; prevalence of known diabetes in Asians and Europeans. BMJ 291: 1081-1084

2. Simmonds D, Williams DRR, Powell MJ (1991) The Coventry Diabetes Study: prevalence of diabetes and impaired glucose tolerance in Europeans and Asians. Q J Med 8 (296): 1021-1030

3. Nisbet JA, Eastwood JB, Costan KW et al. (1990) Detection of osteomalacia in British Asians; a comparison of clinical score with biochemical measurements. Clin Sci 78: 383389

4. Bickle DD (1992) Clinical counterpoint: vitamin D; new actions, new analogues, new therapeutic potential. Endocr Rev 13 (4): 765-784

5. Reichel H, Koeffler HP, Norman AW (1989) The role of the vitamin $\mathrm{D}$ endocrine system in health and disease. New Engl J Med 32 (15): 980-991

6. Mak RH (1992) Intravenous 1,25 dihydroxycholecalciferol corrects glucose intolerance in haemodialysis patients. Kidney Int 41: 1049-1054

7. Grodsky GM, Bennet LL (1966) Cation requirements for insulin secretion in the isolated perfused pancreas. Diabetes 15 (12): 910-913

8. Milner RDG, Hales CN (1967) The role of calcium and magnesium in insulin secretion from rabbit pancreas studied in vitro. Diabetologia 3 (1): 47-49

9. Bansal S, Rizvi SNA, Rao MB et al. (1975) Effect of hypocalcaemia on glucose tolerance, insulin release and free fatty acid levels in human subjects. Postgrad Med 52: 471-475

10. Simmons D, Williams DRR, Powell MJ (1989) Prevalence of diabetes in a predominantly Asian community; preliminary findings of the Coventry diabetes study. BMJ 298 : 18-21

11. WHO Study Group on diabetes mellitus (1985) Diabetes mellitus; report of a WHO study group. World Health Organization Technical Report Series 727. WHO, Geneva

12. Hodgin P, Kay GH, Hine PM et al. (1973) Vitamin D deficiency in Asians at home and in Britain. Lancet I: 167-172

13. Davis CE (1976) The effect of regression to the mean in epidemiologic and clinical studies. Am J Epidemiol 104: 493498

14. Mannan N (1992) Vitamin D status and its relationship to insulin levels in the Bangladeshi community of Tower Hamlets and to the contribution of fish oil to the diet. MSc Thesis. University of London

15. Snehalatha C, Ramachandran A, Vijay V et al. (1994) Differences in plasma insulin responses in urban and rural Indians: a study in Southern Indians. Diabet Med 11: 445-448

16. Beaulieu C, Kestekian R, Havrankova J et al. (1993) Calcium is essential in normalizing intolerance to glucose that accompanies vitamin $\mathrm{D}$ depletion in vivo. Diabetes $42: 35-$ 43
17. Gedik O, Akalin S (1986) Effects of vitamin D deficiency and repletion on insulin and glucagon secretion in man. Diabetologia 29: 142-145

18. Barragry J, France MF, Corless D et al. (1978) Intestinal cholecalciferol absorption in the elderly and in younger adults. Clin Sci Mol Med 55: 213-220

19. Stephens WP, Klimiuk PS, Warrington S et al. (1982) Seasonal changes in serum 25-hydroxyvitamin D concentrations among Asian immigrants. Clin Sci 63: 577-580

20. Davidson HW, Rhodes CJ, Hutton JC (1988) Intraorganellar calcium and $\mathrm{pH}$ control proinsulin cleavage in the pancreatic beta cell via two site-specific endopeptidases. $\mathrm{Na}$ ture 333: 93-96

21. Inomata S, Kadowaki S, Yamatani Tet al. (1986) Effect of 1 alpha $(\mathrm{OH})$-vitamin D3 on insulin secretion in diabetes mellitus. Bone Miner 1 (3): 187-192

22. McLaughlin M, Fairney A, Lester E et al. (1974) Seasonal variations in serum 25 -hydroxy cholecalciferol in healthy people. Lancet I: 536-537

23. Lu KC, Shieh SD, Lin SH et al. (1994) Hyperparathyroidism, glucose tolerance and platelet intracellular free calcium in chronic renal failure. Q J Med 87 (6): 359-365

24. Orwoll E, Riddle M, Prince M (1994) Effects of vitamin D on insulin and glucagon secretion in non-insulin-dependent diabetes mellitus. Amer J Clin Nut 59 (59): 1083-1087

25. Ljunghall S, Lind L, Lithell H et al. (1987) Treatment with one-alpha-hydroxycholecalciferol in middle-aged men with impaired glucose tolerance - a prospective randomized double-blind study. Acta Med Scand 222 (4): 361-367

26. Kocian J (1992) Diabetic osteopathy. Favourable effect of treatment of osteomalacia with vitamin $\mathrm{D}$ and calcium on high blood glucose levels. Vnitr Lek 38 (4): 352-356

27. Feskens EJM, Bowles CH, Kromhart D (1991) Inverse association between fish intake and risk of glucose intolerance in normoglycaemic elderly men and women. Diabetes Care 14: 935-941

28. Samanta A, Burden AC (1989) Diabetes mellitus is a major risk factor for acute myocardial infarction in Asians. Diabet Med 6 [Suppl 1]: A30 (Abstract)

29. Nagi DK, Hendra TJ, Ryle AJ et al. (1990) The relationships of concentrations of insulin, intact proinsulin and 3233 split proinsulin with cardiovascular risk factors in type 2 (non-insulin-dependent) diabetic subjects. Diabetologia 33: 532-537

30. Maxwell JD (1994) Seasonal variation in vitamin D. Proc Nut Soc 53: 533-543

31. Lin SH, Lin YF, Lu KC et al. (1994) Effects of intravenous calcitrol on lipid profiles and glucose tolerance in uraemic patients with secondary hyperparathyroidism. Clin Sci 87 : $533-538$

32. Burr ML, Fehily AM, Gilbert JF et al. (1989) Effects of changes in fat, fish, and fibre intakes on death and myocardial reinfarction: Diet and Reinfarction Trial (DART). Lancet II: $757-761$ 